\title{
Labour productivity among small- and medium-scale enterprises in Uganda: the role of innovation
}

\author{
Ibrahim Mike Okumu* and Faisal Buyinza
}

\author{
* Correspondence: okumuim@gmail. \\ com \\ School of Economics, Makerere \\ University, P.O. Box 7062, Kampala, \\ Uganda
}

\begin{abstract}
Using the 2013 World Bank Enterprise Survey data for Uganda, this paper employs the quintile estimation technique to explain the relationship between labour productivity and innovation among SMEs. Innovation involves the introduction of a new or significantly improved production process, product, marketing technique or organisational structure. Our results indicate that the relationship between labour productivity and a firm engaging in any form of innovation is neutral. However, there is evidence of complementarity among product, process, marketing and organisational innovation. Specifically, there is a positive association between labour productivity and innovation when a firm engages in all the four innovation types. Even then, the complementarity effect turns out weakly positive with incidences of negative relationship when using any combination of innovations that are less than the four types of innovations. Our results suggest that efforts to incentivise innovation should be inclusive enough to induce all the four forms of innovation.
\end{abstract}

Keywords: Innovation, Labour productivity, SMEs, Uganda

\section{Background}

SMEs ${ }^{1}$ can potentially play a critical role in enabling households engage in income generating activities and as a source of decent employment opportunities. Also, through offering forward and backward linkages, SMEs equally open up economic participation space for households. Backward linkages involve the supply of inputs to SMEs while forward linkages could be through buying output from SMEs as inputs higher up the value chain. Furthermore, SMEs are partly incubators of innovations that could enhance an economy's productivity and economic growth potential. In Uganda for example, SMEs which are in the industrial, services and agricultural sectors employ about 2.5 million people (GoU 2011) besides contributing approximately $18 \%$ to its GDP (GoU 2015). Also, Uganda's tax to GDP ratio has persistently failed to pass $13 \%$ and SMEs are a potential source of revenue. As such, recent tax reforms have intensively and extensively targeted SMEs both in the formal and informal segments in an attempt to expand the tax to GDP ratio to 20\% by 2020 .

For SMEs to have a significant contribution to Uganda's economy partly depends on improving their performance and specifically enhancing labour productivity. Labour productivity is a measure of how much each employee contributes to a firm's output. The higher an SME's labour productivity, the higher its likelihood for growth. This is

(c) The Author(s). 2018 Open Access This article is distributed under the terms of the Creative Commons Attribution 4.0 International License (http://creativecommons.org/licenses/by/4.0/), which permits unrestricted use, distribution, and reproduction in any medium, provided you give appropriate credit to the original author(s) and the source, provide a link to the Creative Commons license, and indicate if changes were made. 
because highly productive firms command higher profits, thus being able to employ more workers through firm expansion and pay more taxes among others.

Labour productivity partly depends on innovation prospects among SMEs. Innovation is apparent among SMEs in Uganda; for example, from the 2013 World Bank Enterprise Survey (WBES) dataset for Uganda, out of the 698 SMEs, 58\%, 62\%, 56\% and 48\% of them engaged in process, ${ }^{2}$ product, ${ }^{3}$ marketing ${ }^{4}$ and organisational ${ }^{5}$ innovation respectively. Engaging in marketing, process, organisational and product innovation could lead to increased labour productivity. Specifically, product innovation involves the introduction of new and superior products resulting in potentially higher sales and thus productivity gains (Harrison et al. 2014). Process innovation involves improvements in production efficiency which induces a reduction in the unit cost of production (Harrison et al. 2014), thereby resulting in reduced prices, higher product sales and hence labour productivity gains. Similarly, organisational innovation has the potential of strengthening firm efficiency through for example introducing better communication strategies among workers or even with customers. Therefore, organisational innovation equally has the potential of reducing the unit cost of production which results in lower prices, higher sales and hence labour productivity gains. Finally, marketing innovation has the potential of increasing a firm's market share, implying increased sales and hence labour productivity gains.

There is a consensus in the developed world empirical literature that innovation enhances labour productivity (Griffin et al. 2006; Griffith et al. 2004; Mairesse and Mohnen 2010; Mairesse et al. 2005; OECD 2009). However, evidence in the developing world literature is rather contradicting; for example, in Sub-Saharan Africa (SSA), Chowdhury and Wolf (2003) argue that innovation (proxied by Information Communication and Technology $\left.(\mathrm{ICT})^{6}\right)$ dampens labour productivity among SMEs. Similarly, Goedhuys et al. (2008) show that product or process innovation has no significant impact on labour productivity. On the other hand, Esselaar et al. (2007) show that innovation (proxied by ICT) enhances labour productivity among SMEs. The non-convergence in the innovation and labour productivity relationship is equally prevalent among empirical studies in other developing economies. For example, empirical studies in Latin America have argued that innovation has no impact on labour productivity (Perez et al. 2005; Benavente 2006; Raffo et al. 2008; Crespi and Zuniga 2012). On the contrary, Raffo et al. (2008) show that product innovation has a significant impact on labour productivity.

The lack of consensus on the relationship between innovation and labour productivity among developing economies could partly be associated with using inaccurate proxies for innovation such as ICT. Indeed, Lin and Chen (2007) argues that ICT may not be critical to for example labour productivity at least when compared to say organisational innovation. While in some instances, at least in Latin America, investment in research and development (R\&D) was used as a proxy for innovation which while it could be relevant for developed economies as they are at the frontier of innovation, this may not be the case for developing economies that typically engage in imitation of innovation (Naudé et al. 2011). As such, investment in R\&D as a proxy for innovation may not significantly impact labour productivity in developing countries while it enhances labour productivity in developed economies (Crespi and Zuniga 2012).

This paper therefore further delves into the innovation and labour productivity relationship in the developing world with Uganda as a case study. Our contribution to empirical literature is twofold: first, we use the 2013 WBES where innovation is measured by 
whether a firm introduced a new or significantly improved (1) marketing technique, (2) organisational structure and (3) product and (4) production process in the last 3 years prior to the survey implementation to explain the relationship between innovation and labour productivity proxied by sales per worker. These proposed measures of innovation are better than proxying innovation using ICT (Lin and Chen 2007) and investment in R\&D (Naudé et al. 2011). Secondly, we contribute to the empirical literature by exploring whether the relationship between labour productivity and innovation could be associated with complementarity effects among different combinations of innovation types. This study thus compares labour productivity among firms that undertook any one innovation, two innovations, three innovations and all the four innovations. We hypothesise that (1) labour productivity is positively associated with innovation and (2) labour productivity is positively associated with innovation when a firm engages in more than one innovation.

The subsequent section is a review of empirical literature. The 'Methods' section presents the methodology where the empirical strategy and data characteristics are explained. The 'Results and discussion' section presents the results from the empirical model estimation alongside the discussion. Finally, the 'Conclusions' section presents the conclusion and policy recommendations arising from the paper.

\section{Review of empirical literature}

There is no consensus regarding the relationship between innovation and labour productivity in SSA. For example, using a firm-level dataset for Kenya and Tanzania, Chowdhury and Wolf (2003) find that innovation (proxied by ICT) is inversely related with labour productivity. However, with the aid of a cross-country dataset of 14 African countries, Esselaar et al. (2007) argue that innovation (proxied by ICT) enhances labour productivity across both formal and informal SMEs. The contradiction in the relationship between innovation and labour productivity could be partly because administrative innovations as opposed to technological innovations for example ICT are the most critical factor in explaining the labour productivity (Lin and Chen 2007). Furthermore, ICT is not a perfect match for process or organisational or product or marketing innovation. Indeed, as opposed to proxying innovation using ICT, Goedhuys et al. (2008) use a cross-sectional firm-level data on Tanzania from the World Bank Investment Climate Survey to measure innovation by way of whether a firm engaged in product or process innovation. Even then, engaging in product or process innovation was shown to have no significant impact on labour productivity (Goedhuys et al. 2008).

Similar studies in Latin America also show that innovation may not significantly impact firm productivity. For example, Raffo et al. (2008) with the aid of a cross-sectional dataset for manufacturing firms in Argentina show that engaging in product innovation does not significantly impact labour productivity. Similarly, using Mexican firm-level dataset, innovation was shown not to have a significant impact on labour productivity (Perez et al. 2005). Consistent with Perez et al. (2005), Benavente (2006) using Chilean firm-level data shows that innovation has no impact on labour productivity. On the contrary, using a cross-sectional dataset for six Latin American countries, Crespi and Zuniga (2012) show that engaging in product or process innovation enhances labour productivity. Similarly, Raffo et al. (2008) using a cross-sectional dataset for manufacturing firms in Brazil and Mexico argue that product innovation enhances labour productivity. 
The non-convergence in relationship between innovation and firm performance in the developing world is in contradiction to the consensus in developed world literature in which innovation is argued to enhance labour productivity (Griffin et al. 2006; Griffith et al. 2004; Mairesse and Mohnen 2010; Mairesse et al. 2005; OECD 2009). This perhaps suggests that there is room to further explore the innovation-labour productivity relationship in developing countries. It is in that regard that this paper undertakes to explain the relationship between innovation and labour productivity using the 2013 WBES data for Uganda. Consistent with Lin and Chen (2007), we measure innovation using whether a firm engaged in process, organisational, product and marketing innovation as opposed to ICT utilization which Chowdhury and Wolf (2003) and Esselaar et al. (2007) used in explaining labour productivity in East Africa and SSA respectively. This paper further contributes to empirical literature by exploring the potential of complimentary among process, product, marketing and organisational innovations in their relationship with labour productivity (Appendix 1 and Appendix 2).

\section{Methods}

\section{Empirical strategy}

Like in Lachenmaier (2007), our analysis of the relationship between labour productivity and innovation assumes that innovation enters the production function as an input. We control for additional observable variables $X_{i j}$ and non-observable random variable $\varepsilon_{i j}$ (see Eq. 1 ).

$$
Q_{i j}=f\left[\operatorname{Innov}_{i j}, X_{i j}, \varepsilon_{i j}\right]
$$

From Eq. 1, $i$ and $j$ index the firm and sector respectively. Innov is a categorical variable that captures the number of innovations undertaken by a firm that is no innovation, one innovation, two innovations, three innovations and four innovations, while $Q_{i j}$ denotes firm $i$ s labour productivity in sector $j$.

We hypothesise that innovation has a positive association with labour productivity. An increase in labour productivity as a result of the adoption of innovation holding other inputs constant is defined as a 'direct' effect of innovation on labour productivity. Therefore, it can generally be expected that an increase in labour productivity could result from the direct effect of innovation. Specifically, innovation for example process or organisational innovation is likely to result in reduced production or operational costs. The reduction in production or operational costs could for example be in form of a leaner workforce which may induce price reduction. Price reduction would in turn potentially increase sales resulting in higher labour productivity.

However, whether a firm realises more sales and therefore increased labour productivity as a result of adopting new innovations depends on its market share and thus its initial monopolistic position. For example, given a product innovation, the innovating firm with a high market share is likely to charge a higher product price resulting potentially in more sales revenue leading to a higher labour productivity. On the other hand, if an innovating firm has a small market share, it is likely to benefit less especially given the presence of existing highly competitive firms. This is because even with innovation the firm with a small market share has no power to influence prices in an already competitive product market thereby potentially rendering sales unchanged thus compromising improvements in labour 
productivity. Also, in case a firm introduces a new or improved product which turns out unsuccessful perhaps because the new product is not accepted by the market or new processes do not result in the desired cost reduction under such circumstances, innovation is likely to have a negative or neutral association with labour productivity.

The preceding discussion suggests that the relationship between innovation and labour productivity is indeterminate. Thus, one should expect that as a result of interacting effects, innovation at firm level will produce alternative outcomes depending on the concrete characteristics of the firm, in conjunction with auxiliary factors. Also, the different types and quality of innovation may vary among firms and this may have divergent effects on labour productivity, whether positive or negative or neutral. Understanding the relationship between labour productivity and innovation activity could provide useful insights for innovation investment decisions.

Therefore, to investigate the relationship between innovation and labour productivity, this study employs quintile regression techniques. Quintile regression is preferred over the standard least squares method for this analysis for a number of reasons. First, unlike ordinary least squares (OLS) that is prone to outliers, quintile regression results are characteristically robust to outliers and heavy-tailed distributions. As such, the quintile regression solution $\hat{\beta}$ is invariant to outliers of the dependent variable that tend to $\pm \infty$ (Buchinsky 1994). Also, unlike a conventional regression that focuses on the mean, quintile regressions are able to describe the entire conditional distribution of the dependent variable. In the context of this study, SMEs have different levels of labour productivity which are of interest in their own right. Thus, in order not to dismiss firms with low labour productivity or high labour productivity as outliers, it is worthwhile to study them in detail by calculating coefficient estimates at various quintiles of the conditional distributional. In addition, quintile regressions avoid the restrictive assumption that the error terms are identically distributed at all points of the conditional distribution. Thus, relaxing these assumptions implies accommodation of firm heterogeneity among SMEs such that the estimated slope parameters do vary at different quintiles of the distribution. From Eq. 1, our quintile model follows Koeneker and Bassett (1978) and is given as:

$$
Q_{i j}=X_{i j}^{\prime} \beta_{\theta}+\varepsilon_{i j} \text { with Quant }{ }_{\theta}\left[Q_{i j} \mid X_{i j}\right]=X_{i j}^{\prime} \beta_{\theta}
$$

From Eq. 2, $Q_{i j}$ denotes firm $i$ s labour productivity in sector $j, X_{i j}$ is a vector of regressors of firm $i$ in sector $j, \beta$ is the vector of parameters to be estimated and $\varepsilon_{i j}$ is a vector of residuals. Quant $\theta_{\theta}\left(Q_{i j} \mid X_{i j}\right)$ denotes the $\theta$ th conditional quintile of $Q_{i j}$ given $X_{i j}$, where $0<\theta<1$, therefore solving the following problem:

$$
\frac{\operatorname{Min}}{\beta} \frac{1}{n}\left\{\sum_{\mathrm{ij}, Q \geq X_{i j \beta}^{\prime}} \theta\left|Q_{i j}-X_{i j \beta}^{\prime}\right|+\sum_{i j, Q<X_{i j \beta}^{\prime}}(1-\theta)\left|Q_{i j}-X_{i j \beta}^{\prime}\right|\right\}=\frac{\operatorname{Min} 1}{\beta} \frac{1}{n} \sum_{i j=1}^{n} \rho_{\theta}\left(\varepsilon_{\theta_{i j}}\right)
$$

From Eq. 3, $\rho_{\theta}($.$) denotes the model check function which is defined as:$

$$
\rho_{\theta}\left(\varepsilon_{\theta_{i j}}\right)=\left\{\begin{array}{c}
\theta \varepsilon_{\theta_{i j}} \text { if } \varepsilon_{\theta_{i j}} \geq 0 \\
(\theta-1) \varepsilon_{\theta_{i j}} \text { if } \varepsilon_{\theta_{i j}}<0
\end{array}\right\}
$$


From Eq. 4, it can be noted that as $\theta$ increases continuously from 0 to 1 , one is able to trace the entire conditional distribution of $Q$, conditional on $X$ when Eq. 4 is solved using linear programming techniques.

To therefore examine the relationship between innovation and labour productivity, we estimate the following empirical model:

$$
Q_{i j}=\beta_{0}+\beta_{1} \operatorname{Innov}_{i j}+\beta_{2} Z_{i j}+\beta_{3} X_{i j}+\beta_{4} \delta_{i j}+\beta_{5} \gamma_{i j}+\varepsilon_{i j}
$$

From Eq. 5, $Q$ is a measure of labour productivity. Innov is a categorical variable that captures the number of innovations undertaken by a firm that is no innovation (Innovation_0), one innovation (Innovation_1), two innovations (Innovation_2), three innovations (Innovation_3) and four innovations (Innovation_4). $X$ is a vector of business climate characteristics that is land access, labour education, credit access, electricity supply, corruption and tax rate. $Z$ is a vector of firm characteristics such as firm age, experience, gender, ICT, certification and export; $\gamma$ captures regional fixed effects; $\delta$ captures sectoral fixed effects; and $\varepsilon$ are error terms that are assumed to be identically and independently distributed.

Note that out of a dataset of 698 observations, labour productivity has 247 missing values (see Appendix 3). The existence of missing labour productivity values suggests a risk of selection bias in estimation. This is because the labour productivity missing values are generated through a non-random process. To address the risk of selection bias, we first examine the missingness patterns and how frequently they occur among our variables of interest, and indeed, we establish that only 347 firms have non-missing values among all the variables of interest excluding labour cost. ${ }^{7}$ Also, we generate the variable m_labour productivity which takes a value of ' 1 ' for a firm where the value of labour productivity is missing otherwise '0'. Therefore, following Svensson (2003) and Mawejje and Okumu (2016), we attempt to understand whether firms with missing or non-missing labour productivity values differ significantly across observed firm characteristics such as age, experience, certification, labour cost, export and Innov. We thus estimate logit models where the aforementioned firm characteristics are the independent variables while m_labour productivity is the dependent variable (Appendix 4). From the missing variable models 1 (logit coefficients) and 2 (odds ratio), there is no evidence of firms missing the labour productivity values differing significantly in light of observable characteristics when compared to firms that have labour productivity values.

\section{Data description}

This study uses the 2013 WBES data for Uganda which was collected between January and August 2013. The survey employed stratified random sampling technique so as to (1) get rid of biased estimates for the entire population, (2) get rid of biased estimates for different subdivisions of the population with a given degree of informed precision, (3) ensure that different sectors are well represented in the final sample and (4) benefit from the precision associated with population estimates in stratified sampling as opposed to simple random sampling among others. The survey was based on a sampling frame obtained from Uganda Bureau of Statistics. In terms of stratification, the survey employed three levels of stratification that is region, size and industry. In terms of region, the survey was undertaken in Jinja (central Eastern Uganda), Kampala (Capital City found in central Uganda), Lira (Northern 
Uganda), Mbale (Eastern Uganda), Mbarara (Western Uganda) and Wakiso (Central Uganda). In terms of size, the survey covered small, medium and large enterprises. Small enterprises comprised of firms with 5 to 19 employees, medium enterprises compromised of firms with 20 to 99 employees while large firms had 100+ employees. The data was collected from only formal (registered) firms with 5 or more employees.

With regard to our study, we have a sample of 698 SMEs of which 324 SMEs were surveyed in the manufacturing sector which included food, textiles, garments, tobacco, leather, wood, paper, publishing, printing, and recorded media, refined petroleum products, chemicals, plastics and rubber, non-metallic mineral products, basic metals, fabricated metal products, machinery and equipment, electronics, precision instruments, transport machines, furniture and recycling (see Fig. 1 and Appendix 1). Furthermore, within the manufacturing sector, the number of small- and medium-scale firms was 180 and 144 respectively. While the service sector had a total of 374 firms surveyed which included retail, wholesale, IT, hotel and restaurants, services of motor vehicles, construction and transport among others (see Fig. 1 and Appendix 1). Specifically, 280 and 94 small-scale and medium-scale firms were surveyed respectively.

Labour productivity is measured as a firm's total annual sales in the fiscal year prior to the survey divided by the number of permanent full time employees at the firm in the fiscal year prior to the survey. The mean labour productivity is Uganda shillings (UGX) 329 million. The minimum and maximum labour productivity is UGX 24,000 and UGX 39,000 million respectively. On average, Lira has the highest labour productivity (UGX 848 million), while on average, Jinja has the lowest labour productivity (UGX 18.5 million). Kampala which doubles as the capital and commercial city has an average labour productivity of UGX 430 million. Note however that in the estimation, we consider labour productivity in logarithms to avoid using labour productivity in levels as this would amplify heterogeneity effects in the distribution. That is, by using logarithms, we re-scale the effects, thus avoiding

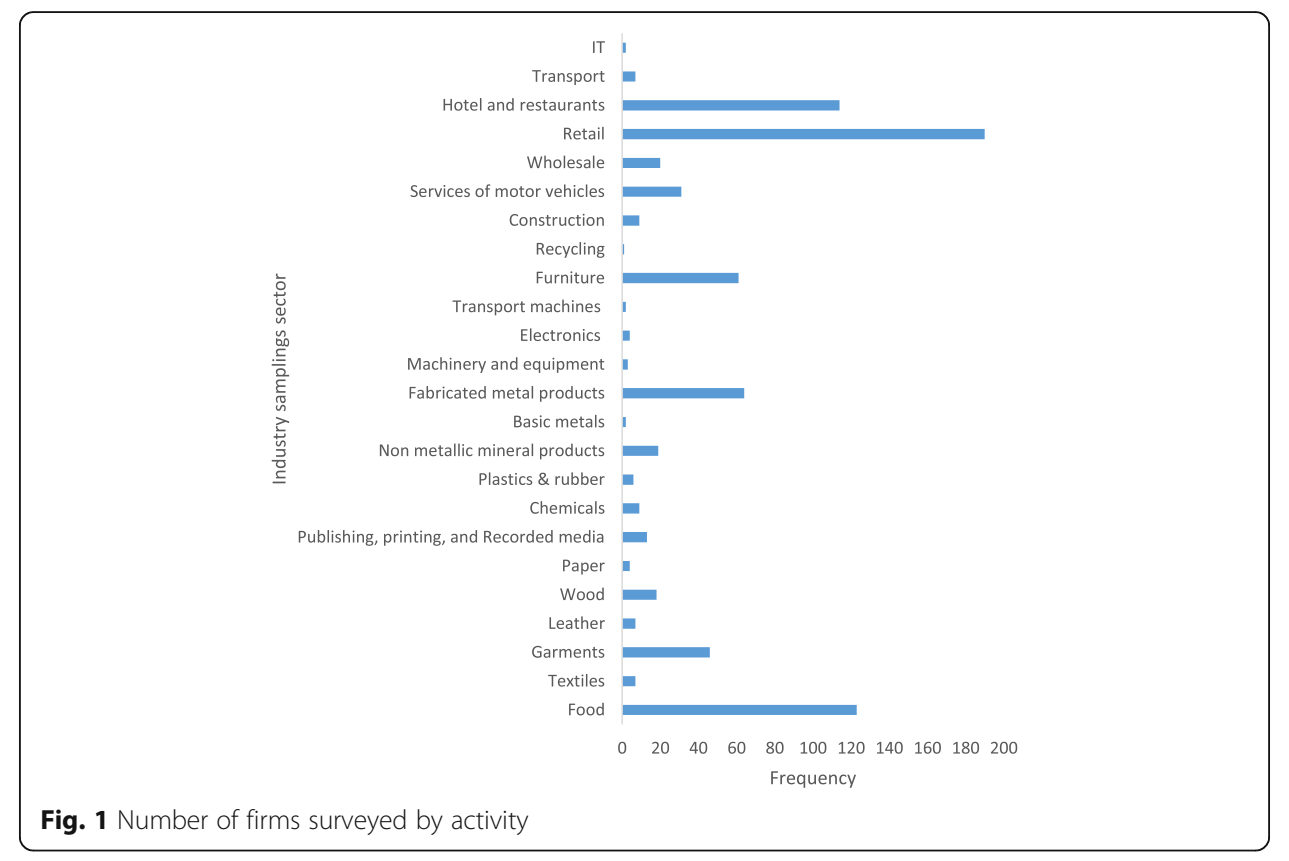


such an amplification. The data characteristics of labour productivity in logarithms are captured in Table 1.

Innov is a categorical variable that captures the number of innovations undertaken by a firm that is no innovation (Innovation_0), one innovation (Innovation_1), two innovations (Innovation_2), three innovations (Innovation_3) and four innovations (Innovation_4). Specifically, Innovation_ 0 captures firms that did not undertake any innovation in the last 3 years prior to the survey. On average, $24 \%$ of firms did not engage in any kind of innovation. Innovation_ 1 measures firms that undertook any one type of innovation in the last 3 years prior to the survey. On average, $12 \%$ of the firms undertook any one type of innovation. Innovation_2 captures firms that undertook any two combinations of innovation types in the last 3 years prior to the survey. On average, 13\% of firms undertook any two combinations of innovation types. Innovation_ 3 captures firms that undertook any three combinations of innovation types in the last 3 years prior to the survey. On average, 18\% of firms engaged in

Table 1 Summary statistics

\begin{tabular}{|c|c|c|c|c|c|c|}
\hline Variable & $N$ & Mean & $\mathrm{Sd}$ & p50 & $\min$ & $\max$ \\
\hline Sales per worker & 451 & 16.31607 & 2.093108 & 16.13052 & 10.08581 & 24.38683 \\
\hline Value added per worker & 128 & 15.98301 & 2.114016 & 15.90234 & 11.0021 & 24.38681 \\
\hline Firm size $($ medium $=1)$ & 698 & 0.3409742 & 0.4743766 & 0 & 0 & 1 \\
\hline Labour cost & 410 & 16.48001 & 1.932582 & 16.31032 & 3.912023 & 24.11104 \\
\hline \multicolumn{7}{|l|}{ Innov } \\
\hline Innovation_1 (yes $=1)$ & 698 & 0.1174785 & 0.3222205 & 0 & 0 & 1 \\
\hline Innovation_2 (yes = 1) & 698 & 0.1318052 & 0.3385214 & 0 & 0 & 1 \\
\hline Innovation_3 (yes = 1) & 698 & 0.1848138 & 0.3884247 & 0 & 0 & 1 \\
\hline Innovation_4 (yes $=1$ ) & 698 & 0.3237822 & 0.4682536 & 0 & 0 & 1 \\
\hline Age & 646 & 15.16563 & 9.899125 & 14 & 2 & 87 \\
\hline Age squared & 646 & 327.8375 & 554.779 & 196 & 4 & 7569 \\
\hline Experience & 670 & 13.37313 & 8.208122 & 12 & 1 & 41 \\
\hline Certification (yes $=1$ ) & 636 & 0.1509434 & 0.3582755 & 0 & 0 & 1 \\
\hline Export (yes $=1$ ) & 698 & 0.0816619 & 0.2740453 & 0 & 0 & 1 \\
\hline $\mathrm{ICT}($ yes $=1$ ) & 698 & 0.1805158 & 0.3848923 & 0 & 0 & 1 \\
\hline Gender (yes $=1$ ) & 698 & 0.8266476 & 0.3788231 & 1 & 0 & 1 \\
\hline Tax rate (obstacle $=1$ ) & 693 & 0.6392496 & 0.4805651 & 1 & 0 & 1 \\
\hline Transport (constraint $=1$ ) & 697 & 0.5093257 & 0.500272 & 1 & 0 & 1 \\
\hline Land access (constraint $=1$ ) & 671 & 0.414307 & 0.4929695 & 0 & 0 & 1 \\
\hline Corruption (obstacle $=1$ ) & 692 & 0.5375723 & 0.498947 & 1 & 0 & 1 \\
\hline Labour education (obstacle $=1$ ) & 691 & 0.4109986 & 0.4923714 & 0 & 0 & 1 \\
\hline Electricity (obstacle $=1$ ) & 697 & 0.6011478 & 0.4900139 & 1 & 0 & 1 \\
\hline Credit access (obstacle $=1$ ) & 677 & 0.7060561 & 0.4559034 & 1 & 0 & 1 \\
\hline Sector $($ manufacturing $=1$ ) & 698 & 0.4641834 & 0.4990732 & 0 & 0 & 1 \\
\hline \multicolumn{7}{|l|}{ Region } \\
\hline Jinja (yes = 1) & 698 & 0.1217765 & 0.327262 & 0 & 0 & 1 \\
\hline Lira (yes $=1$ ) & 698 & 0.0558739 & 0.2298428 & 0 & 0 & 1 \\
\hline Mbale (yes = 1) & 698 & 0.1117479 & 0.3152819 & 0 & 0 & 1 \\
\hline Mbarara $($ yes $=1$ ) & 698 & 0.1332378 & 0.3400753 & 0 & 0 & 1 \\
\hline Wakiso (yes $=1$ ) & 698 & 0.0959885 & 0.2947868 & 0 & 0 & 1 \\
\hline
\end{tabular}


any three combinations of innovation types. Innovation_4 captures firms that undertook all the four types of innovation in the last 3 years prior to the survey. On average, $32 \%$ of firms engaged in four innovations (see Table 1). In the empirical estimation, Innovation_ 0 is the reference variable.

Firm age defines the number of years a firm has been in existence. The mean age of the firms is 15 years to suggest that on average many of the firms are mid-aged. The youngest and oldest firm is 2 and 87 years old respectively. Gender measures if the firm manager is a female, and it takes a value of ' 1 ' if yes, otherwise ' 0 '. On average, $17 \%$ of firms are managed by female managers. Export measures a firm's export status, and it takes a value of ' 1 ' if a firm exports, otherwise ' 0 '. One average, $8 \%$ of firms engage in exports. ICT is a measure of ICT usage which takes on a value of ' 1 ' when a firm has either an email account or website or both, otherwise ' 0 '. On average, $18 \%$ of firms have either an email account or website or both. Certification measures if a firm has an internationally recognised quality certification. It takes a value ' 1 ' if yes, otherwise ' 0 '. On average, $15 \%$ of firms have an internationally recognised product quality certification. Experience measures the number of years of experience that the top management has been working in the sector. The average years of experience of top management is 13 years.

With regard to the business environment characteristics, land access measures whether land access is a constraint as perceived by a firm. It takes a value of ' 1 ' if land access is a constraint, otherwise ' 0 '. On average, $41 \%$ of firms perceive land access to be a constraint. Tax rate measures whether a firm perceives the tax rate to be an obstacle. It takes a value of ' 1 ' if the tax rate is an obstacle, otherwise ' 0 '. On average, $64 \%$ of firms perceive the tax rate to be a constraint. Labour education measures how inadequately educated labour force is an obstacle. It takes a value of ' 1 ' if inadequately educated labour force is perceived as an obstacle, otherwise ' 0 '. On average, $41 \%$ of firms perceive labour education to be a constraint. Transport measures whether a firm perceives transport as a constraint. It takes a value of ' 1 ' if transport is a constraint, otherwise ' 0 '. On average, $51 \%$ of firms perceive transport to be a constraint. Credit access measures how much of an obstacle is access to finance as perceived by a firm. It takes a value of ' 1 ' if credit access is an obstacle, otherwise ' 0 '. Corruption measures how much of an obstacle is corruption as perceived by a firm. It takes a value of ' 1 ' if corruption is an obstacle, otherwise ' 0 '. On average, $54 \%$ of firms perceive corruption to be a constraint. Electricity measures how much of an obstacle is electricity supply as perceived by a firm. It takes a value of ' 1 ' if electricity supply is an obstacle, otherwise ' 0 '. On average, $60 \%$ of firms perceive electricity to be a constraint. Credit access measures how much of an obstacle is access to finance as perceived by a firm. It takes a value of ' 1 ' if credit access is an obstacle, otherwise ' 0 '. On average, $71 \%$ of firms perceive credit access to be an obstacle.

Sector fixed effects controls for the sector in which a firm engages its business and takes on a value of ' 1 ' if manufacturing otherwise ' 0 '. Regional fixed effects controls for the location of a firm where Kampala is a reference region and thus compared to a firm located in Wakiso, Mbale, Jinja, Mbarara and Lira.

\section{Results and discussion}

From Table 2, while our paper provides better measures for innovation evidently, the OLS estimation (model 1) result for innovation_ 1 indicates that firms engaging in only one form of innovation are not significantly different from non-innovating firms in terms of labour productivity, other factors held constant. We further sought to understand whether the 
Table 2 Innovation and labour productivity

\begin{tabular}{|c|c|c|c|c|}
\hline Variables & $\begin{array}{l}\text { Model } 1 \\
\text { OLS }\end{array}$ & $\begin{array}{l}\text { Model } 2 \\
25 \text { th percentile }\end{array}$ & $\begin{array}{l}\text { Model } 3 \\
50 \text { th percentile }\end{array}$ & $\begin{array}{l}\text { Model } 4 \\
\text { 75th percentile }\end{array}$ \\
\hline \multicolumn{5}{|l|}{ Innov } \\
\hline Innovation 1 & $\begin{array}{l}0.181 \\
(0.445)\end{array}$ & $\begin{array}{l}0.026 \\
(0.917)\end{array}$ & $\begin{array}{l}0.181 \\
(0.445)\end{array}$ & $\begin{array}{l}-0.345 \\
(0.163)\end{array}$ \\
\hline Innovation_2 & $\begin{array}{l}-0.258 \\
(0.292)\end{array}$ & $\begin{array}{l}0.190 \\
(0.456)\end{array}$ & $\begin{array}{l}-0.258 \\
(0.292)\end{array}$ & $\begin{array}{l}-0.711^{* * *} \\
(0.006)\end{array}$ \\
\hline Innovation_3 & $\begin{array}{l}0.217 \\
(0.309)\end{array}$ & $\begin{array}{l}0.405^{*} \\
(0.069)\end{array}$ & $\begin{array}{l}0.217 \\
(0.309)\end{array}$ & $\begin{array}{l}-0.482^{* *} \\
(0.030)\end{array}$ \\
\hline Innovation_4 & $\begin{array}{l}0.641^{* * *} \\
(0.001)\end{array}$ & $\begin{array}{l}0.968^{* * *} \\
(0.000)\end{array}$ & $\begin{array}{l}0.641^{* * *} \\
(0.001)\end{array}$ & $\begin{array}{l}-0.040 \\
(0.845)\end{array}$ \\
\hline Firm age & $\begin{array}{l}0.056^{* *} \\
(0.011)\end{array}$ & $\begin{array}{l}-0.004 \\
(0.854)\end{array}$ & $\begin{array}{l}0.056^{* *} \\
(0.011)\end{array}$ & $\begin{array}{l}-0.020 \\
(0.375)\end{array}$ \\
\hline Firm age squared & $\begin{array}{l}-0.880^{* *} \\
(0.029)\end{array}$ & $\begin{array}{l}0.201 \\
(0.631)\end{array}$ & $\begin{array}{l}-0.880^{* *} \\
(0.030)\end{array}$ & $\begin{array}{l}1.111^{* * *} \\
(0.007)\end{array}$ \\
\hline Manager's years' experience & $\begin{array}{l}0.007 \\
(0.506)\end{array}$ & $\begin{array}{l}0.049^{* * *} \\
(0.000)\end{array}$ & $\begin{array}{l}0.007 \\
(0.506)\end{array}$ & $\begin{array}{l}0.005 \\
(0.633)\end{array}$ \\
\hline Certification ( 1 = yes) & $\begin{array}{l}0.077 \\
(0.710)\end{array}$ & $\begin{array}{l}-0.424^{*} \\
(0.050)\end{array}$ & $\begin{array}{l}0.077 \\
(0.710)\end{array}$ & $\begin{array}{l}-0.502^{* *} \\
(0.021)\end{array}$ \\
\hline Exporter ( 1 = yes) & $\begin{array}{l}0.703^{* *} \\
(0.019)\end{array}$ & $\begin{array}{l}1.460^{* * *} \\
(0.000)\end{array}$ & $\begin{array}{l}0.703^{* *} \\
(0.019)\end{array}$ & $\begin{array}{l}1.301^{* * *} \\
(0.000)\end{array}$ \\
\hline Use ICT (1 = yes) & $\begin{array}{l}1.534^{* * *} \\
(0.000)\end{array}$ & $\begin{array}{l}1.315^{* * *} \\
(0.000)\end{array}$ & $\begin{array}{l}1.534^{* * *} \\
(0.000)\end{array}$ & $\begin{array}{l}1.496^{* * *} \\
(0.000)\end{array}$ \\
\hline Gender ( 1 = yes) & $\begin{array}{l}0.150 \\
(0.364)\end{array}$ & $\begin{array}{l}-0.208 \\
(0.228)\end{array}$ & $\begin{array}{l}0.150 \\
(0.364)\end{array}$ & $\begin{array}{l}0.033 \\
(0.849)\end{array}$ \\
\hline Tax rate burden $(1=$ yes $)$ & $\begin{array}{l}-0.553^{* * *} \\
(0.000)\end{array}$ & $\begin{array}{l}-0.619^{* * *} \\
(0.000)\end{array}$ & $\begin{array}{l}-0.553^{* * *} \\
(0.000)\end{array}$ & $\begin{array}{l}-0.762^{* * *} \\
(0.000)\end{array}$ \\
\hline Transport burden ( 1 = yes) & $\begin{array}{l}-0.202 \\
(0.172)\end{array}$ & $\begin{array}{l}-0.217 \\
(0.159)\end{array}$ & $\begin{array}{l}-0.202 \\
(0.172)\end{array}$ & $\begin{array}{l}0.619^{* * * *} \\
(0.000)\end{array}$ \\
\hline Land access ( 1 = yes) & $\begin{array}{l}-0.084 \\
(0.566)\end{array}$ & $\begin{array}{l}-0.022 \\
(0.885)\end{array}$ & $\begin{array}{l}-0.084 \\
(0.566)\end{array}$ & $\begin{array}{l}-0.096 \\
(0.533)\end{array}$ \\
\hline Corruption ( 1 = yes) & $\begin{array}{l}0.102 \\
(0.513)\end{array}$ & $\begin{array}{l}-0.083 \\
(0.606)\end{array}$ & $\begin{array}{l}0.102 \\
(0.513)\end{array}$ & $\begin{array}{l}-0.621^{* * *} \\
(0.000)\end{array}$ \\
\hline Labour education ( 1 = yes) & $\begin{array}{l}-0.283^{*} \\
(0.075)\end{array}$ & $\begin{array}{l}-0.073 \\
(0.659)\end{array}$ & $\begin{array}{l}-0.283^{*} \\
(0.075)\end{array}$ & $\begin{array}{l}-0.493^{* * *} \\
(0.003)\end{array}$ \\
\hline Electricity burden ( 1 = yes) & $\begin{array}{l}-0.0641 \\
(0.649)\end{array}$ & $\begin{array}{l}0.033 \\
(0.822)\end{array}$ & $\begin{array}{l}-0.064 \\
(0.649)\end{array}$ & $\begin{array}{l}-0.023 \\
(0.874)\end{array}$ \\
\hline Credit access ( 1 = yes) & $\begin{array}{l}0.320^{* *} \\
(0.041)\end{array}$ & $\begin{array}{l}-0.169 \\
(0.302)\end{array}$ & $\begin{array}{l}0.320^{* *} \\
(0.042)\end{array}$ & $\begin{array}{l}0.467^{* * *} \\
(0.005)\end{array}$ \\
\hline Sectoral fixed effects & Yes & Yes & Yes & Yes \\
\hline Regional fixed effects & Yes & Yes & Yes & Yes \\
\hline Constant & $\begin{array}{l}15.350^{* * *} \\
(0.000)\end{array}$ & $\begin{array}{l}15.340^{* * *} \\
(0.000)\end{array}$ & $\begin{array}{l}15.350^{* * *} \\
(0.000)\end{array}$ & $\begin{array}{l}17.940^{* * *} \\
(0.000)\end{array}$ \\
\hline Observations & 347 & 347 & 347 & 347 \\
\hline$R^{2}$ & 0.138 & 0.118 & 0.138 & 0.161 \\
\hline
\end{tabular}

$p$ value in parentheses ${ }^{* * *} p<0.01,{ }^{* *} p<0.05,{ }^{*} p<0.1$

relationship between innovation and labour productivity is uniform across different quintiles; even then, at the 25th percentile (low labour productivity firms), 50th percentile (medium which is similar to OLS) and 75th percentile (high labour productivity firms), engaging in any one form of innovation is not associated with an increase or decrease in labour productivity, other factors held constant. Implying that irrespective of a firm's level 
of labour productivity, firms that engage in only one innovation are not significantly different from non-innovating firms in terms of labour productivity.

Our results are consistent with other emerging economy findings in Latin America, for example Benavente (2006) and Perez et al. (2005) who show that the relationship between innovation and labour productivity is neutral. Also, Raffo et al. (2008) show that product innovation has no effect on labour productivity among manufacturing firms. Our finding is also consistent with studies in SSA, for example Goedhuys et al. (2008) show that firm engagement in either product or process innovation has no significant impact on value added per worker (labour productivity). The consistence in finding among Benavente (2006), Perez et al. (2005) and Goedhuys et al. (2008) could be attributed to a limited time lag between adoption of innovation and measuring its effects on labour productivity (Benavente 2006). However, our dataset implicitly allows for a fairly long time lag between adoption of innovation and measuring its association with labour productivity. This is because firms for example responded to the question: during the last 3 years, has this establishment introduced any new or significantly improved: method of a manufacturing product or offering services? Key here is 'during the last three years' as it allows for a lag between the acquisition of an innovation and learning how to effectively use the innovation (adoption and adaptation). This gives us a better platform to estimate the relationship between innovation and labour productivity. Even then, our results indicate that the relationship between innovation and labour productivity is neutral. However, it is possible that innovation is associated with embodied technical change which is not captured by our dataset, hence limiting our study to labour productivity.

We furthermore attempt to understand whether the relationship between labour productivity and innovation could be better captured upon taking care of complementarity among different kinds of innovation. Recall that the variable Innov has three more categories capturing firms that engaged in any two (Innovation_2), three (Innovation_3) and four (Innovation 4) kinds of innovations. From Table 1, the OLS model indicates that in comparison to non-innovating firms, engaging in all the four forms of innovation is associated with an increase in labour productivity, other factors held constant. The relationship remains strong and positive among firms with low labour productivity (25th percentile) although no effect is shown among firms with high labour productivity (at the 75th percentile). Our results thus suggests that engaging in all the four forms of innovation is associated with increased labour productivity especially among low labour productivity firms. This implies the presence of complementarity among the four different kinds of innovation in how they relate with labour productivity especially among low productivity firms.

Furthermore, engaging in any three or two forms of innovation has mixed results. For example, the OLS results show that compared to non-innovating firms, engaging in either three or two forms of innovation is not associated with labour productivity. In essence, firms engaging in any three or two forms of innovation are not significantly different from non-innovating firms in terms of labour productivity. However, in comparison to non-innovating firms, engaging in any three forms of innovation is weakly associated with an increase in labour productivity among firms with low labour productivity while it is strongly associated with a reduction in labour productivity among firms with high labour productivity. The inverse relationship between labour productivity and innovation is further strengthened among firms with high labour productivity when a firm engages in any two kinds of innovation. 
While to the best of our literature review no study has attempted to explain the complementarity effects of innovation on labour productivity, our study indicates that the association between labour productivity and innovation is positive only when a firm engages in all the four forms of innovation. Otherwise, the relationship between innovation and labour productivity turns out indeterminate when a firm engages in any two or three combinations of innovation. Even then, our results categorically indicate that the relationship between innovation and labour productivity is neutral among firms that engage in any one form of innovation.

Our study therefore implies that introducing a single innovation is not enough for a firm to experience labour productivity gains. For example, while product innovation results in new and perhaps better quality products being introduced on the market, this might not necessarily result in labour productivity enhancement unless it is complimented with marketing, organisational and process innovation. Marketing innovation would imply for example that a firm's marketing strategy is adjusted to suite the new product besides making the new product known to its potential customers. Process innovation implies that adjustments in the production process are made to ensure that the new product is produced at a minimal unit cost while maintaining the attractiveness of the new product to its potential customers. Finally, organisational innovation would imply re-alignments in the organisational structure to ensure that the new product is efficiently delivered to the market. Therefore, only if innovation is all inclusive would it be associated with productivity gains.

Finally, we test for robustness of the study results by including firm size represented by the variable medium in the empirical model estimated (see Table 3). We observe that firm size does not affect our overall results reported. Therefore, the quintile results clearly show the fact that labour productivity is explained by the selected set of variables included in the empirical model.

\section{Conclusions}

We set out to explain the relationship between innovation and labour productivity. Our results suggest that (1) the relationship between labour productivity and a firm engaging in any one form of innovation is neutral and (2) there is evidence of complementarity among product, process, marketing and organisational innovation in how they relate with labour productivity. The implication of our study is that if a firm seeks to enhance labour productivity through innovation, due consideration ought to be given to product, process, marketing and organisation innovation; otherwise, singlehandedly each innovation may not result in inducing improvements in labour productivity. This in our opinion is the major contribution of this paper.

Our study thus implies that efforts to induce innovation should ensure inclusiveness. The presence of complementarity among the four kinds of innovation suggests that government cannot for example choose to incentivise marketing innovation at the expense of product or organisational or processing innovations. Innovation incentives should be designed in such a way that firms can embrace the four dimensions of innovations. This is because our results indicate that engaging in all the four forms of innovation is associated with an increase in labour productivity.

Finally, our study is not short of limitations. For example, while a panel dataset would have been the most appropriate framework to explain the relationship between innovation and labour productivity especially by capturing inherent dynamics, 
Table 3 Innovation and labour productivity (controlling for firm size)

\begin{tabular}{|c|c|c|c|c|}
\hline Variable & $\begin{array}{l}\text { Model } 1 \\
\text { OLS }\end{array}$ & $\begin{array}{l}\text { Model } 2 \\
25 \text { th percentile }\end{array}$ & $\begin{array}{l}\text { Model } 3 \\
50 \text { th percentile }\end{array}$ & $\begin{array}{l}\text { Model } 4 \\
\text { 75th percentile }\end{array}$ \\
\hline \multicolumn{5}{|l|}{ Innov } \\
\hline Innovation_1 & $\begin{array}{l}0.173 \\
(0.456)\end{array}$ & $\begin{array}{l}0.0146 \\
(0.950)\end{array}$ & $\begin{array}{l}0.173 \\
(0.456)\end{array}$ & $\begin{array}{l}0.0375 \\
(0.874)\end{array}$ \\
\hline Innovation_2 & $\begin{array}{l}-0.185 \\
(0.441)\end{array}$ & $\begin{array}{l}0.260 \\
(0.279)\end{array}$ & $\begin{array}{l}-0.185 \\
(0.441)\end{array}$ & $\begin{array}{l}-0.546^{* *} \\
(0.026)\end{array}$ \\
\hline Innovation_3 & $\begin{array}{l}0.262 \\
(0.212)\end{array}$ & $\begin{array}{l}0.478^{* *} \\
(0.024)\end{array}$ & $\begin{array}{l}0.262 \\
(0.212)\end{array}$ & $\begin{array}{l}-0.0376 \\
(0.860)\end{array}$ \\
\hline Innovation_4 & $\begin{array}{l}0.639^{* * *} \\
(0.001)\end{array}$ & $\begin{array}{l}0.957^{* * *} \\
(0.000)\end{array}$ & $\begin{array}{l}0.639^{* * *} \\
(0.001)\end{array}$ & $\begin{array}{l}0.0840 \\
(0.672)\end{array}$ \\
\hline Firm age & $\begin{array}{l}0.0497^{* *} \\
(0.021)\end{array}$ & $\begin{array}{l}0.00469 \\
(0.827)\end{array}$ & $\begin{array}{l}0.0497^{* *} \\
(0.021)\end{array}$ & $\begin{array}{l}-0.0288 \\
(0.187)\end{array}$ \\
\hline Firm age squared & $\begin{array}{l}-0.802^{* *} \\
(0.042)\end{array}$ & $\begin{array}{l}-0.0750 \\
(0.850)\end{array}$ & $\begin{array}{l}-0.802^{* *} \\
(0.042)\end{array}$ & $\begin{array}{l}1.062^{* * *} \\
(0.008)\end{array}$ \\
\hline Manager's years' experience & $\begin{array}{l}0.0127 \\
(0.214)\end{array}$ & $\begin{array}{l}0.0481^{* * *} \\
(0.000)\end{array}$ & $\begin{array}{l}0.0127 \\
(0.214)\end{array}$ & $\begin{array}{l}0.00249 \\
(0.810)\end{array}$ \\
\hline Certification ( 1 = yes) & $\begin{array}{l}-0.0194 \\
(0.924)\end{array}$ & $\begin{array}{l}-0.362^{*} \\
(0.076)\end{array}$ & $\begin{array}{l}-0.0194 \\
(0.924)\end{array}$ & $\begin{array}{l}-0.217 \\
(0.293)\end{array}$ \\
\hline Exporter ( 1 = yes) & $\begin{array}{l}0.753^{* *} \\
(0.010)\end{array}$ & $\begin{array}{l}1.360^{* * *} \\
(0.000)\end{array}$ & $\begin{array}{l}0.753^{* *} \\
(0.010)\end{array}$ & $\begin{array}{l}1.515^{* * *} \\
(0.000)\end{array}$ \\
\hline Use ICT (1 = yes) & $\begin{array}{l}1.175^{* * *} \\
(0.000)\end{array}$ & $\begin{array}{l}1.439^{* * *} \\
(0.000)\end{array}$ & $\begin{array}{l}1.175^{* * *} \\
(0.000)\end{array}$ & $\begin{array}{l}1.262^{* * *} \\
(0.000)\end{array}$ \\
\hline Gender ( 1 = yes) & $\begin{array}{l}0.125 \\
(0.443)\end{array}$ & $\begin{array}{l}-0.213 \\
(0.193)\end{array}$ & $\begin{array}{l}0.125 \\
(0.443)\end{array}$ & $\begin{array}{l}0.0692 \\
(0.676)\end{array}$ \\
\hline Tax rate burden( 1 = yes $)$ & $\begin{array}{l}-0.540^{* * *} \\
(0.000)\end{array}$ & $\begin{array}{l}-0.570^{* * *} \\
(0.000)\end{array}$ & $\begin{array}{l}-0.540^{* * *} \\
(0.000)\end{array}$ & $\begin{array}{l}-0.930^{* * *} \\
(0.000)\end{array}$ \\
\hline Transport burden (1 = yes) & $\begin{array}{l}-0.197 \\
(0.174)\end{array}$ & $\begin{array}{l}-0.177 \\
(0.221)\end{array}$ & $\begin{array}{l}-0.197 \\
(0.174)\end{array}$ & $\begin{array}{l}0.587^{* * *} \\
(0.000)\end{array}$ \\
\hline Land access ( 1 = yes) & $\begin{array}{l}-0.122 \\
(0.400)\end{array}$ & $\begin{array}{l}-0.00248 \\
(0.986)\end{array}$ & $\begin{array}{l}-0.122 \\
(0.400)\end{array}$ & $\begin{array}{l}-0.224 \\
(0.129)\end{array}$ \\
\hline Corruption ( 1 = yes) & $\begin{array}{l}0.0883 \\
(0.562)\end{array}$ & $\begin{array}{l}-0.102 \\
(0.504)\end{array}$ & $\begin{array}{l}0.0883 \\
(0.562)\end{array}$ & $\begin{array}{l}-0.325^{* *} \\
(0.036)\end{array}$ \\
\hline Labour education ( 1 = yes) & $\begin{array}{l}-0.216 \\
(0.164)\end{array}$ & $\begin{array}{l}-0.0883 \\
(0.571)\end{array}$ & $\begin{array}{l}-0.216 \\
(0.164)\end{array}$ & $\begin{array}{l}-0.361^{* *} \\
(0.023)\end{array}$ \\
\hline Electricity burden ( 1 = yes) & $\begin{array}{l}-0.0981 \\
(0.477)\end{array}$ & $\begin{array}{l}0.0893 \\
(0.519)\end{array}$ & $\begin{array}{l}-0.0981 \\
(0.477)\end{array}$ & $\begin{array}{l}0.0139 \\
(0.921)\end{array}$ \\
\hline Credit access $(1=$ yes $)$ & $\begin{array}{l}0.295^{*} \\
(0.056)\end{array}$ & $\begin{array}{l}-0.188 \\
(0.222)\end{array}$ & $\begin{array}{l}0.295^{*} \\
(0.056)\end{array}$ & $\begin{array}{l}0.506^{* * *} \\
(0.001)\end{array}$ \\
\hline Medium (1 = yes) & $\begin{array}{l}0.471^{* * *} \\
(0.003)\end{array}$ & $\begin{array}{l}-0.161 \\
(0.308)\end{array}$ & $\begin{array}{l}0.471^{* * *} \\
(0.003)\end{array}$ & $\begin{array}{l}0.484^{* * *} \\
(0.003)\end{array}$ \\
\hline Sectoral fixed effects & Yes & Yes & Yes & Yes \\
\hline Regional fixed effects & Yes & Yes & Yes & Yes \\
\hline Constant & $\begin{array}{l}14.92^{* * *} \\
(0.000)\end{array}$ & $\begin{array}{l}15.35^{* * *} \\
(0.000)\end{array}$ & $\begin{array}{l}14.92^{* * *} \\
(0.000)\end{array}$ & $\begin{array}{l}17.15^{* * *} \\
(0.000)\end{array}$ \\
\hline Observations & 347 & 347 & 347 & 347 \\
\hline$R^{2}$ & 0.143 & 0.118 & 0.143 & 0.166 \\
\hline
\end{tabular}

$p$ values in parentheses, ${ }^{* * *} p<0.01,{ }^{* *} p<0.05,{ }^{*} p<0.1$

unfortunately, the innovation variable was not captured in the 2006 WBES for Uganda. As such, we were limited to use the 2013 WBES cross-sectional dataset. Therefore, for purposes of further research, it would be prudent to explore the relationship between innovation and labour productivity in the event a panel dataset is made available. 


\section{Appendix 1}

Table 4 Industries surveyed among SMEs

\begin{tabular}{|c|c|c|}
\hline Industry sampling sector & Frequency & Percent \\
\hline Food & 102 & 14.61 \\
\hline Textiles & 6 & 0.86 \\
\hline Garments & 45 & 6.45 \\
\hline Leather & 4 & 0.57 \\
\hline Wood & 18 & 2.58 \\
\hline Paper & 3 & 0.43 \\
\hline Publishing, printing and recorded media & 12 & 1.72 \\
\hline Chemicals & 7 & 1 \\
\hline Plastics and rubber & 5 & 0.72 \\
\hline Non-metallic mineral products & 15 & 2.15 \\
\hline Basic metals & 2 & 0.29 \\
\hline Fabricated metal products & 57 & 8.17 \\
\hline Machinery and equipment & 3 & 0.43 \\
\hline Electronics & 3 & 0.43 \\
\hline Transport machines & 2 & 0.29 \\
\hline Furniture & 61 & 8.74 \\
\hline Construction & 9 & 1.29 \\
\hline Services of motor vehicles & 29 & 4.15 \\
\hline Wholesale & 18 & 2.58 \\
\hline Retail & 186 & 26.65 \\
\hline Hotel and restaurants & 103 & 14.76 \\
\hline Transport & 6 & 0.86 \\
\hline IT & 2 & 0.29 \\
\hline Total & 698 & 100 \\
\hline
\end{tabular}

\section{Appendix 2}

\section{Variable description}

Value added per worker is the logarithm of the ratio of the difference between a firm's total annual sales in the fiscal prior to the survey and the total cost of raw material in the fiscal year prior to the survey to the number of permanent full time employees at the firm in the fiscal year prior to the survey.

Labour cost measures natural log of the total labour cost which includes wages, salaries and bonuses. 


\section{Appendix 3}

Table 5 Missing and non-missing observations

\begin{tabular}{lll}
\hline Variable & $\begin{array}{l}\text { Number of missing } \\
\text { observations }\end{array}$ & $\begin{array}{l}\text { Number of non-missing } \\
\text { observations }\end{array}$ \\
\hline Labour productivity (sales per worker) & 247 & 451 \\
Labour productivity (value added per & 570 & 128 \\
worker) & 288 & 410 \\
Labour cost & 52 & 646 \\
Age & 52 & 646 \\
Age squared & 28 & 670 \\
Experience & 62 & 636 \\
Certification (yes $=1$ ) & 5 & 693 \\
Tax rate (obstacle $=1$ ) & 1 & 697 \\
Transport (constraint $=1)$ & 27 & 671 \\
Land access (constraint $=1)$ & 6 & 692 \\
Corruption (obstacle $=1)$ & 7 & 691 \\
Labour education $($ obstacle $=1)$ & 1 & 697 \\
Electricity (obstacle $=1)$ & 21 & 677 \\
Credit access (obstacle $=1$ ) & & \\
\hline
\end{tabular}

\section{Appendix 4}

Table 6 Comparison of firms with missing and non-missing sales per worker values

\begin{tabular}{lll}
\hline Dependent variable & $(1)$ & $(2)$ \\
& Logit coefficient & Odds ratio \\
\hline Innov & & \\
Innovation_1 (yes = 1) & 0.766 & 2.151 \\
& $(0.563)$ & $(1.210)$ \\
Innovation_2 (yes = 1) & -0.332 & 0.717 \\
& $(0.443)$ & $(0.318)$ \\
Innovation_3 (yes = 1) & 0.492 & 1.636 \\
& $(0.441)$ & $(0.722)$ \\
Innovation_4 (1 =yes) & 0.377 & 1.458 \\
& $(0.395)$ & $(0.576)$ \\
Experience & 0.0217 & 1.022 \\
& $(0.0222)$ & $(0.0226)$ \\
Certification & -0.0444 & 0.957 \\
& $(0.430)$ & $(0.412)$ \\
Export & 0.776 & 2.173 \\
& $(0.780)$ & $(1.694)$ \\
ICT & -0.0958 & 0.909 \\
Age & $(0.447)$ & $(0.406)$ \\
Labour cost (natural log) & 0.117 & 1.124 \\
Constant & $(0.269)$ & $(0.303)$ \\
& 0.0536 & 1.055 \\
Standarvations & $(0.0723)$ & $(0.0763)$ \\
& -0.251 & 0.778 \\
& $(1.242)$ & $(0.966)$ \\
& 344 & 344 \\
\hline
\end{tabular}

Standard errors in parentheses ${ }^{* * *} p<0.01,{ }^{* *} p<0.05,{ }^{*} p<0.1$ 


\section{Endnotes}

${ }^{1}$ Which in our case are firms employing 5-19 and 20-99 persons henceforth small enterprises and medium enterprises respectively

${ }^{2}$ According to the 2013 WBES, process innovation involves introducing a new or significantly improved method of manufacturing or offering services. Indeed, firms responded to the question, 'During the last 3 years, has this establishment introduced any New or significantly improved products or services?'

${ }^{3}$ According to the 2013 WBES, product innovation could involve improving a firm's existing good or service or simply introducing a new good or service. With regard to product innovation, firms responded to the question 'During the last three years, has this establishment introduced any new or significantly improved methods of manufacturing products or offering services?'

${ }^{4}$ According to the 2013 WBES, marketing innovation involves improvements in product design or packaging, product promotion, product pricing or even product placement. Firms responded to the question 'During the last three years, has this establishment introduced any new or significantly improved logistics, delivery, or distribution methods for inputs, products, or services?' and 'During the last three years, has this establishment introduced new or significantly improved marketing methods?'

${ }^{5}$ According to the 2013 WBES, organisational innovation involves adopting new practices or policies or culture re-orientation of a firm. With respect to organisational innovation, firms responded to the question 'During the last three years, has this establishment introduced any new or significantly improved organizational structures or management practices?'

${ }^{6}$ Such as mobile phones, internet, computers, telephone and fax

${ }^{7}$ With labour cost, the number of firms with all values would be 261. For this reason, we exclude labour cost in the main regression.

\section{Abbreviations}

GDP: Gross domestic product; GoU: Government of Uganda; ICT: Information Communication and Technology:

IT: Information Technology; MSMEs: Micro, small and medium enterprises; OECD: The Organisation for Economic

Co-operation and Development; R\&D: Research and development; SMEs: Small- and medium-scale enterprises;

SSA: Sub-Saharan Africa; UGX: Uganda shillings; WBES: World Bank Enterprise Survey

\section{Acknowledgements}

We appreciate comments from members of Group D_-Production, Trade and Economic Integration, AERC biannual.

Funding

Dr. Faisal Buyinza (my co-author) and I jointly received financing to write this manuscript from the African Economics Research Consortium (AERC), Grant No. RT15526.

AERC, through inviting us for Biannual meetings (we attended three meetings in total), enabled us to receive comments about our methods of analysis, interpretation of data and overall appreciation of the manuscript.

Availability of data and materials

We used the World Bank Enterprise Survey data for Uganda 2013 which is readily available upon request. Please note that we can also avail the do files upon request.

Authors' contributions

While I was the principal researcher on the grant received from AERC, the paper was jointly conceived, developed and written by Dr. FB (my co-author) and I. Both authors read and approved the final manuscript. 
public expenditure, tax evasion, informal economy and income inequality. My research output has appeared in among others South African Journal of Economics, Journal of Entrepreneurship, Management and Sustainable Development and African Journal of Economic review. I am currently using World Bank Enterprise Survey to write different papers about the response of firms to the business environment in Africa. On the other hand, Dr. Okumu is currently a senior lecturer at the School of Economics, Makerere University. He is also an associate researcher at the Economic Policy Research Center, Makerere University, and a research affiliate of the Centre for Dynamic Macroeconomic Analysis, University of St Andrews. Dr. Okumu holds a PhD in Economics of the University of St Andrews (UK), MA Economics of McMaster University (Canada) and BA Economics of Makerere University (Uganda).

Dr. Faisal Buyinza is a senior lecturer at the School of Economics, Makerere University. Dr. Buyinza holds a PhD from Johannes Kepler University Linz, Austria; MA Economics of the University of Dar es-Salaam-Tanzania; and BA Economics of Makerere University, Uganda.

\section{Competing interests}

The authors declare that they have no competing interests.

\section{Publisher's Note}

Springer Nature remains neutral with regard to jurisdictional claims in published maps and institutional affiliations.

Received: 5 November 2017 Accepted: 26 September 2018

Published online: 12 October 2018

\section{References}

Benavente, J. M. (2006). The role of research and innovation in promoting productivity in Chile. Economics of Innovation and New Technology, 154(4-5), 301-315.

Buchinsky, M. (1994). Changes in the U.S. wage structure 1963-1987: application of quantile regression. Econometrica, 62(2), 405-458.

Chowdhury, K. S., \& Wolf, S. (2003). Use of ICTs and the economic performance of SMEs in East Africa. United Nations University, World Institute of Development Research, discussion paper no. 2003/06.

Crespi, G., \& Zuniga, P. (2012). Innovation and productivity: evidence from six Latin American countries. World Development, $40(2), 273-290$.

Esselaar, S., Stork, C., Ndiwalana, A., \& Deen-Swarray, M. (2007). ICT usage and its impact on profitability of SMEs in 13 African countries. Information Technologies and International Development, 4(1), 87-100.

Goedhuys, M., Janz, K., \& Mohnen, P. (2008). What drives productivity in Tanzanian manufacturing firms: technology or business environment? European Journal of Development Research, 20(2), 199-218.

Government of Uganda (2011). Development of a national micro, small and medium enterprises (MSMEs) policy and strategy, Ministry of Finance, planning and economic development.

Government of Uganda (2015). Uganda micro, small and medium enterprise policy sustainable: MSMEs for wealth creation and socio-economic transformation, Ministry of Trade, Industry and Cooperatives.

Griffin, R., Huego, E., Mairesse, J., \& Peters, E. (2006). Innovation and productivity across four European countries. Oxford Review of Economic Policy, 22(4), 483-498.

Griffith, R., Redding, S., \& Van Reenen, J. (2004). Mapping the two faces of R\&D: productivity growth in a panel of OECD industries. The Review of Economics and Statistics, 86(4), 883-895.

Harrison, R., Jaumandreu, J., Mairessee, J., \& Peters, B. (2014). Does innovation stimulate employment? A firm-level analysis using comparable micro-data from four European countries. International Journal of Industrial Organization, 35, 29-43.

Koeneker, R., \& Bassett, G. (1978). Regression quantiles. Econometrica, 46, 33-50.

Lachenmaier, S., 2007. Effects of innovation on firm performance. Mimeo.

Lin, C. Y., \& Chen, Y., (2007). Does innovation lead to firm performance? An empirical study of SMEs in Taiwan. Managing Research News, 30(2), 115-132.

Mairesse, J., \& Mohnen, P. (2010). Using innovations surveys for econometric analysis. In B. H. Hall \& N. Rosenberg (Eds.), The handbook of economics of innovation (pp. 1129-1155). Amsterdam: North-Holland Publications, Elsevier.

Mairesse, J., Mohnen, P., \& Kremp, E. (2005). The importance of R\&D and innovation for productivity: a reexamination in light of the 2000 French innovation survey. Annales d'Economie Statistique, no. 79/80, contributions in memory of Zvi Griliches (pp. 487-527).

Mawejje, J., \& Okumu, I. M. (2016). Tax evasion and the business environment in Uganda. South African Journal of Economics, 84(3), 440-460

Naudé, W., Szirmai, A., \& Goedhuys, M. (2011). Innovation and entrepreneurship in developing countries. United Nations University policy brief no. 1.

OECD. (2009). Innovation in firms: a microeconomic perspective. Paris: Organization for Economic Cooperation and Development.

Perez, P., Dutrenit, D., \& Barceinas, F. (2005). Actividad innovadora y desempeno economico: Un analisis econometrico del caso Mexicano. Indicadores de Ciencia y Tecnologia en Iberoamerica. Buenos Aires: RICYT.

Raffo, J., Lhuillery, S., \& Miotti, L. (2008). Northern and southern innovativity: a comparison across European and Latin American countries. European Journal of Development Research, 20(2), 219-239.

Svensson, J. (2003). Who must pay bribes and how much? Evidence from a cross section of firms. The Quarterly Journal of Economics, 118(1), 207-230. 